\begin{tabular}{c}
\hline KEMAS 10 (2) (2015) 160-168 \\
Jurnal Kesehatan Masyarakat
\end{tabular}

\title{
PERILAKU PENCEGAHAN INFEKSI MENULAR SEKSUAL PADA WANITA PEKERJA SEKSUAL KABUPATEN TEGAL
}

\author{
Dessi Aryani, Mardiana ${ }^{\bowtie}$, Dina Nur Anggraini Ningrum
}

Jurusan Kesehatan Masyarakat Universitas Negeri Semarang

\section{Info Artikel}

Sejarah Artikel:

Diterima 18 Oktober 2014

Disetujui 20 November 2014

Dipublikasikan Januari 2015

Keywords:

sexually transmitted

infections;

female sex workers.

\begin{abstract}
Abstrak
Wanita Pekerja Seks merupakan kelompok risiko tinggi terkena IMS dan paling berpengaruh dalam persebaran IMS. Lokalisasi Peleman berada di Kabupaten Tegal, dengan kasus IMS lebih dari 50\%. Penelitian ini bertujuan untuk mengetahui gambaran perilaku WPS dalam upaya pencegahan IMS di Lokalisasi Peleman. Jenis penelitian menggunakan metode penelitian kualitatif dengan teknik pengambilan informan snowball sampling. Informan berjumlah 6 WPS, 6 teman WPS, 6 mucikari dan 1 petugas keseha$\tan$ Puskesmas Jatibogor. Teknik pengambilan data berupa wawancara mendalam dan observasi. Analisis data dilakukan secara deskriptif dan disajikan dalam bentuk narasi. Penelitian ini dilakukan tahun 2014. Hasil penelitian menunjukkan bahwa WPS cukup aktif mencari informasi IMS melalui teman, petugas kesehatan, penyuluhan, media cetak dan elektronik, tetapi tidak melalui mucikari. Hampir semua WPS merayu pelanggan untuk memakai kondom dan dapat memakai kondom dengan baik. Vaginal higiene WPS belum baik, mereka membersihkan vagina bagian dalam menggunakan antiseptik dan pasta gigi.
\end{abstract}

\section{SEXUALLY TRANSMITTED INFECTIONS PREVENTION BEHAVIOR OF FEMALE SEXUAL WORKERS IN TEGAL DISTRICT}

\begin{abstract}
Female sex workers are the high risk group to be infected STIs and the most influential group that responsible for the spreading of STIs. Peleman prostitution site is located in Tegal district which has more than 50\% STIs case. The purpose of this research is to find out the image of female sex workers behaviour in the effort of STIs prevention in Peleman prostitution site. This research was qualitative research and used snowball sampling technique. Informant for this research amounts 6 FSW, 6 FSW's friends, 6 pimps, and 1 health workers of Puskesmas Jatibogor. The data collection in this research used in-depth interview and observation. The data analyzed descriptively and presented in narrative form. This result was held in 2014 year. The result showed that FSW were quite actively looking for STIs information through friends, health workers, elucidation, print and electronic media, but not through a pimp. Almost all of FSW asked costumers to used condoms and could use condoms properly. Vaginal hygiene of FSW has not been good, they really cleaned the inside of vagina using an antiseptic and toothpaste.
\end{abstract}

(C) 2015 Universitas Negeri Semarang 


\section{Pendahuluan}

Infeksi Menular Seksual (IMS) merupakan berbagai infeksi yang dapat menular dari satu orang ke orang yang lain melalui kontak seksual. Infeksi Menular Seksual (IMS) lebih berisiko bila melakukan hubungan seksual dengan berganti-ganti pasangan baik melalui vagina, oral maupun anal. IMS yang populer di Indonesia antara lain gonore dan sifilis. Salah satu penyakit dari IMS yang belum dapat disembuhkan adalah HIV/AIDS. Faktor terjadinya penyebaran HIV/AIDS disebabkan karena perilaku seks bebas, merosotnya nilai agama, gaya hidup, pekerjaan, dan gagalnya membina rumah tangga (Naila Kamila, 2009; Dewi Rohkmah, 2014).

Lokalisasi Peleman yang berada di desa Sidoharjo Kecamatan Suradadi merupakan satu dari tujuh lokalisasi yang berada di Kabupaten Tegal dengan jumlah WPS paling banyak yaitu sebanyak 150 WPS dan memiliki 59 wisma sebagai tempat tinggal maupun tempat untuk transaksi seksual. Lokalisasi Peleman setiap satu bulan sekali diadakan penyuluhan mengenai IMS dan dibagikan kondom secara gratis pada WPS meski begitu kejadian IMS pada WPS Lokalisasi Peleman selalu tinggi. Berdasarkan laporan bulanan Infeksi Menular Seksual tahun 2013 Klinik IMS Puskesmas Jatibogor didapatkan data bulan SeptemberNovember 2013 lebih dari 90\% WPS terkena Servisitis dan bulan September-Desember 2013 lebih dari 70\% WPS terkena infeksi lainlain seperti $B V$, Bubo Kandilomata, $L G V$.

Studi pendahuluan yang dilakukan pada tanggal 28 Desember 2013 pada 5 orang WPS di Lokalisasi Peleman diketahui bahwa 4 orang dengan pendidikan terakhir SMP, 1 orang SD. Usia dari 5 WPS yaitu 31 tahun, 28 tahun, 24 tahun, 21 tahun dan 33 tahun dengan status perkawinan 2 orang kawin, 2 orang cerai hidup, 1 orang tidak kawin. Penghasilan rata-rata yang mereka dapat untuk satu kali transaksi short time mencapai 150-200 ribu rupiah, sedangkan untuk long time atau pelanggan sampai menginap dikenai biaya 400-500 ribu rupiah. Rata-rata pelanggan yang mereka layani dalam satu hari adalah 2 orang atau 14 orang dalam seminggu. Masa kerja mereka sebagai WPS beragam dari yang baru 6 hari menjadi
WPS hingga 4 tahun dan semua berasal dari luar kota antara lain, 2 orang dari batang, 1 orang dari pemalang, 1 orang dari cianjur dan 1 orang dari jepara. Dalam seminggu terakhir WPS melakukan transaksi, WPS tidak selalu memakai kondom karena ada beberapa pelanggan yang menolak memakai kondom.

Kabupaten Tegal merupakan salah satu kabupaten/kota di Jawa Tengah yang perlu mendapatkan perhatian khusus mengenai kasus IMS. Jumlah kumulatif kasus HIV/AIDS Kabupaten Tegal sejak tahun 1993 hingga tahun 2012 menduduki peringkat ke-9 seJawa Tengah dan menduduki peringkat ke-5 menurut jumlah kumulatif HIV/AIDS dari bulan Januari sampai dengan 31 Desember tahun 2012. Kasus HIV/AIDS yang tinggi, menunjukkan bahwa kabupaten Tegal berisiko tinggi terjadi penularan HIV/AIDS mengingat letaknya berada di titik temu jalur pantai utara menuju jalur pantai selatan. Mobilitas penduduk secara tidak langsung dapat mempengaruhi penyebaran penyakit IMS.

Nur Azmi (2008) menyatakan bahwa kasus IMS yang terus meningkat di Kabupaten Tegal berasal dari populasi berisiko tinggi yaitu Pekerja Seks Komersial (PSK). KPA Kabupaten Tegal juga mengungkapkan bahwa menjelang akhir tahun 2013 kasus HIV/AIDS pada WPS menduduki peringkat kedua setelah ibu rumah tangga. Penularan virus HIV pada ibu rumah tangga diduga kuat ditularkan oleh para suami mereka yang suka berganti-ganti pasangan tidak resmi.

Saat ini Jawa Tengah menduduki urutan pertama dengan laporan jumlah AIDS terbanyak dari bulan Januari hingga Maret 2013 yaitu sebanyak 175 kasus (Dinkes Propinsi Jateng, 2013: 3). Selain itu jumlah kasus baru IMS propinsi Jateng mencapai 8.671 kasus. Jumlah kasus IMS menurun dibandingkan tahun 2011 (10.752) meskipun demikian kemungkinan kasus yang sebenarnya di populasi masih banyak yang belum terdeteksi.

WPS merupakan kelompok resiko tinggi terkena IMS dan berpengaruh penting dalam persebaran IMS, oleh karena itu diperlukan upaya-upaya pencegahan yang dilakukan WPS ketika bertransaksi seksual dengan pelanggannya. Berdasarkan latar belakang di atas, penulis tertarik untuk mengetahui lebih 
mendalam mengenai "Gambaran Perilaku Wanita Pekerja Seks (WPS) dalam Upaya Pencegahan Infeksi Menular Seksual (IMS) di Lokalisasi Peleman Desa Sidoharjo Kecamatan Suradadi Kabupaten Tegal" melalui pendekatan kualitatif dengan fokus penelitian keaktifan WPS dalam mencari informasi tentang IMS, negosiasi WPS kepada pelanggan dalam memakai kondom, memakai kondom dengan benar dan vaginal higiene dari WPS.

\section{Metode}

Jenis penelitian ini adalah studi observasional dengan pendekatan kualitatif. Bogdan (1975:5), penelitian kualitatif adalah penelitian yang menghasilkan data deskriptif berupa kata-kata tertulis atau lisan dari orang-orang dan perilaku yang dapat diamati. Desain yang digunakan dalam penelitian ini adalah fenomenologi. Pengambilan sampel dengan teknik snowball sampling yaitu teknik pengambilan sampel sumber data, yang pada awalnya jumlahnya sedikit, lama-lama menjadi besar hingga data yang didapat memuaskan. Jumlah sampel penelitian ini adalah 6 informan utama, 6 informan triangulasi mucikari WPS, 6 informan triangulasi teman WPS, 1 informan triangulasi petugas kesehatan Puskesmas Jatibogor.

Pengumpulan data dilakukan dengan observasi non partisipatif, wawancara mendalam dan dokumentasi. Instrumen yang digunakan lembar observasi, pedoman wawancara mendalam dan alat perekam. Teknik analisis data yang digunakan adalah analisis isi.

\section{Hasil dan Pembahasan}

\section{Karakteristik Informan Penelitian}

Penelitian yang dilakukan dari akhir Januari sampai awal Maret 2014, diperoleh 6 informan utama, 6 informan triangulasi teman WPS, 6 informan triangulasi mucikari dan 1 informan petugas Puskesmas Jatibogor. Karakteristik informan utama pada penelitian ini dapat dilihat pada Tabel 1.

Usia informan yang berada dalam kelompok umur 20-30 tahun sebanyak 4 orang, kelompok umur 30-40 tahun hanya terdiri dari 2 orang. Pendidikan terakhir informan utama bervariasi mulai dari putus sekolah saat sekolah dasar hingga tamat SMA/SMK. Bahkan ada 1 informan utama yang pernah duduk di bangku perkuliahan salah satu universitas negeri di Jawa Tengah, namun karena video asusila miliknya tersebar di kampus, dia merasa malu hingga memutuskan untuk berhenti kuliah. Seluruh informan berasal dari luar kota yaitu berasal dari Kabupaten Brebes, Kota Semarang, Kota Cirebon, Kabupaten Pemalang dan Kabupaten Purbalingga.

Seluruh informan tidak terikat oleh suatu perkawinan karena status perkawinan mereka terdiri dari kawin cerai hidup/mati dan tidak kawin. Mereka berprofesi sebagai WPS karena tidak terikat pernikahan yang mengharuskan mereka menghidupi diri sendiri dan keluarga. Lama informan utama menjadi WPS di lokalisasi Peleman beragam mulai dari satu bulan hingga 5 tahun.

Tingkat pendidikan yang rendah dan tidak memiliki keahlian membuat informan justru terjun menjadi seorang wanita pekerja

Tabel 1. Karakteristik informan utama (WPS)

\begin{tabular}{clclllc}
\hline $\begin{array}{c}\text { Infor } \\
\text { man }\end{array}$ & Nama & $\begin{array}{c}\text { Umur } \\
\text { (th) }\end{array}$ & Alamat Wisma/ Kota Asal & Pendidikan & $\begin{array}{c}\text { Status } \\
\text { Perkawinan }\end{array}$ & $\begin{array}{c}\text { Lama Bekerja } \\
\text { (bln) }\end{array}$ \\
\hline 1 & OS & 34 & W. Pondok Indah/Semarang & Tamat SMA & Cerai Hidup & 60 \\
2 & DY & 20 & W. Zein/ Cirebon & Tamat SMP & Cerai Hidup & 36 \\
3 & CA & 23 & W.Dian Paramita/Semarang & Tamat SMA & Tidak Kawin & 12 \\
4 & LI & 21 & W.Lucky Star/Brebes & Tamat SMP & Tidak Kawin & 36 \\
5 & PT & 33 & W.Sukorejo/Pemalang & Tidak Tamat SD & Cerai Hidup & 48 \\
6 & ID & 22 & W.Predator/Purbalingga & Tamat SMK & Cerai Hidup & 1 \\
\hline
\end{tabular}

Sumber : data primer 
seks. Menurut Green tingkat pendidikan merupakan salah satu faktor predisposing dalam membentuk perilaku kesehatan. Notoatmodjo juga menjelaskan bahwa tingkat pendidikan seseorang akan mempengaruhi wawasan dan cara pandang dalam menghadapi masalah. Seseorang dengan tingkat pendidikan tinggi cenderung mengedepankan rasio saat menghadapi gagasan baru dibandingkan seseorang dengan pendidikan yang rendah (Nur Azmi, 2008).

Kemampuan informan dalam menjangkau pelayanan kesehatan jika dilihat secara materi (uang) dapat diketahui bahwa tidak semua informan mampu menjangkau pelayanan kesehatan yang ada. Meski terdapat kesulitan untuk menjangkau pelayanan kesehatan, tetapi informan dapat memanfaatkan IMS mobile untuk memeriksakan diri mereka baik seputar pemeriksaan alat kelamin maupun untuk pemeriksaan medis yang lain secara gratis dan tidak memerlukan biaya menuju tempat pemeriksaan (masih dalam lingkungan Lokalisasi Peleman). Selain itu, jika memang perlu obat maka informan dapat mendapatkan secara gratis.

Kemampuan informan dalam menjangkau pelayanan kesehatan berbeda dengan kemampuan informan untuk menjangkau alat kontrasepsi khususnya kondom. Informan mendapatkan kondom secara gratis dari pihak Puskesmas maupun LSM, baik saat IMS mobile ataupun penyuluhan. Jika kebetulan WPS kehabisan kondom, maka WPS akan membeli kondom di warung dekat wisma (jaraknya tidak lebih dari 50 meter). Harga kondom yang relatif murah (Rp 5000,00Rp 10.000,00 per dus berisi 6-12 piece kondom) membuat WPS mampu membeli dari luar, tidak hanya mengandalkan kondom gratis yang dibagikan oleh Puskesmas atau LSM. Akses yang mudah dalam mendapatkan kondom dapat membuat WPS lebih bersemangat dalam merayu tamu untuk memakai kondom.

Sebagian besar WPS telah memanfaatkan media cetak maupun media elektronik untuk mencari informasi tentang IMS. Media cetak yang sering digunakan berupa leaflet dan selebaran fotocopian materi IMS (50\%) sedangkan media elektronik yang dipakai berupa browsing melalui Handphone (33\%) dan menonton tayangan televisi (33\%), seperti yang tertuang dalam pernyataan di bawah ini :

\author{
"waktu habis kumpulan kan dapet itunya \\ tak baca..” \\ Informan 2 \\ “...dari internet doank, buka internet \\ pake HP...” \\ Informan 6 \\ "pernah liat di tivi, kalo HIV badannya \\ semakin kurus..." \\ Informan 5
}

Semua WPS aktif mencari informasi melalui petugas kesehatan baik ketika penyuluhan $(50 \%)$ maupun pemeriksaan /IMS mobile (100\%), tetapi tidak kepada mucikari (83\%) dan teman sesama WPS (50\%). Alasan WPS tidak aktif bertanya kepada mucikari karena mucikari justru sering bertanya kepada WPS tentang IMS dan mucikari tidak memperhatikan kesehatan anak buah. Informan utama juga mengaku risih apabila bertanya kepada teman sesama WPS karena takut pertanyaan justru menyinggung teman. Berikut kutipannya :
"kadang tanya kadang nggak, temen- temen kesehatan banyak yang kenal. Tanya soal keluhan.."
Informan 1
"ga pernah, mamih malah sering tanya ke kita"
Informan 2
"ya kadang-kadang tanya sama yang udah lama di sini (teman yang lebih dahulu menjadi WPS)"
Informan 3

Media cetak merupakan alat bantu untuk menyampaikan pesan-pesan atau informasi secara tertulis baik berupa tulisan maupun gambar. Kelebihan media cetak (Notoatmodjo, 2005) yang dapat dibawa kemana-mana, tahan lama, mencakup orang banyak, biayanya yang tidak tinggi, mudah dipahami, serta tidak memerlukan teknologi yang canggih untuk mengakses, memudahkan WPS aktif mencari informasi melalui media cetak. Media cetak hanya membutuhkan kemampuan membaca untuk dapat mengaksesnya. Oleh karena itu WPS di Lokalisasi Peleman cukup aktif mengakses media cetak sebagai media promosi kesehatan mengenai IMS dan HIV/ 
AIDS. Hal ini bertentangan dengan penelitian Hafrida dkk (2008) yang menyebutkan bahwa media promosi berupa poster, stiker, booklet, folder kurang diminati karena tulisan dan isi pesan dinilai tidak sesuai dengan kebutuhan di lokalisasi. Aktifnya WPS dalam membaca media cetak sebagai media promosi kesehatan dapat membawa perubahan perilaku positif terhadap pencegahan IMS. Akses informasi menjadi faktor pemungkin dalam perubahan perilaku seksual positif. Penelitian yang dilakukan oleh Elly N, dkk (2009) menyatakan bahwa informasi yang diterima berpengaruh dengan perilaku berisiko tertular.

Keaktifan WPS dalam mencari informasi melalui petugas kesehatan, lebih percaya dengan petugas kesehatan juga menunjukkan bahwa WPS cukup memperhatikan kesehatan. Sejalan dengan penelitian Hafrida dkk (2008) yang menyatakan bahwa pendekatan individual kepada WPS oleh petugas kesehatan dapat mengubah sikap dan perilaku WPS dalam menawarkan dan menggunakan kondom serta memeriksakan kesehatan reproduksinya. Selain itu WPS cukup aktif bertanya kepada sesama teman lokalisasi/ satu wisma, baik tentang IMS maupun bukan IMS. Informasi dari teman sebenarnya membawa pengaruh yang lebih besar karena belajar dari pengalaman lebih efektif daripada membaca. Mereka menanggapi secara positif akan kehadiran dari informasi tersebut. Informasi dari teman WPS dapat mengubah pengetahuan WPS yang lain dari tidak tahu menjadi tahu, dari tidak mau berobat menjadi mau berobat. Namun informasi yang mereka dapatkan dari teman belum tentu benar, ada juga yang kurang tepat atau bercampur dengan mitos sebelumnya yang sudah lama dipegang.

WPS enggan berkomunikasi mengenai kesehatan mereka kepada mucikari dengan alasan mucikari justru lebih sering tanya pada WPS, mucikari kurang memperhatikan kesehatan WPS, dan WPS merasa lebih baik tanya ke petugas kesehatan karena petugas kesehatan lebih tahu tentang IMS. Hal ini menunjukkan bahwa antara WPS dan mucikari belum tercipta suatu hubungan yang baik dimana mucikari kurang memperhatikan kesehatan WPS. Oleh karena itu, perlu dilakukan pendampingan terhadap mucikari agar pengetahuan mucikari meningkat dan lebih memperhatikan kesehatan anak buah (WPS). Adanya pelatihan serta pendampingan terhadap mucikari di lokalisasi akan membangkitkan kesadaran dan semangat untuk merubah perilaku WPS dalam meningkatkan derajat kesehatan di lingkungan mereka. Selain itu, dengan pengetahuan yang dimiliki, mucikari dapat memberikan pengertian dan pengetahuan kepada anak asuhnya mengenai kesehatan reproduksi, IMS, dan HIV/AIDS.

Semua informan utama menyatakan bahwa sebelum bertransaksi seksual (hubungan seksual dengan pelanggan), informan selalu mengajak pelanggan untuk memakai kondom ketika di ruang karaoke/ ruang tamu wisma. Cara WPS merayu pelanggan bermacammacam mulai dari menawarkan style vagina yang berbeda, oral seks, memasangkan kondom dengan mulut hingga mengingatkan bahwa keluarga pelanggan dapat tertular IMS apabila pelanggan tidak mau memakai kondom. Berikut penjelasannya:

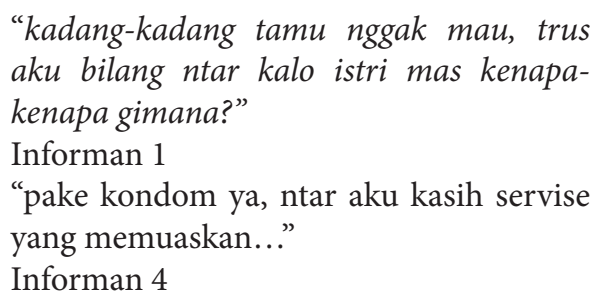
aku bilang ntar kalo istri mas kenapakenapa gimana?"

WPS selalu mengajak pelanggan menggunakan kondom namun tidak pada pacar atau orang yang mereka sukai. Menurut mereka, mereka sudah mengenal pasangan mereka dengan baik dan yakin pasangan mereka sehat. Sebelum bertransaksi, WPS sudah menyediakan beberapa kondom dan pelumas untuk keperluan mereka ketika melayani pelanggan. Kondom yang biasa ditawarkan WPS kepada pelanggan merupakan kondom yang biasa didapatkan dari petugas kesehatan. Kondom berwarna putih bening dan tidak beraroma. Terkadang pelanggan menginginkan kondom dengan merek yang lain dan beraroma, sehingga WPS harus membeli kondom terlebih dahulu di warung terdekat. Merek "Sutra" dan "Fiesta" menjadi merek kondom favorit yang digunakan oleh pelanggan sedangkan untuk pelumas yang sering digunakan WPS yaitu pelumas merek 
Sutra. Sebagian WPS (50\%) tidak menggunakan pelumas ketika berhubungan seksual terlebih lagi ketika menggunakan kondom karena kondom sudah terlapisi oleh pelumas. WPS justru menggunakan pelumas ketika pelanggan tidak memakai kondom karena WPS takut apabila tidak menggunakan pelumas vaginanya akan lecet dan sakit.

WPS tidak selalu menerima pelanggan apabila pelanggan tidak mau memakai kondom. Penolakan juga pernah dilakukan WPS meski hal ini jarang dilakukan mengingat kebutuhan WPS harus tetap terpenuhi. Penolakan tidak semata pelanggan tidak mau memakai kondom tetapi WPS tidak menyukai pelanggan secara fisik atau nada bicaranya yang kasar. Berikut kutipannya:

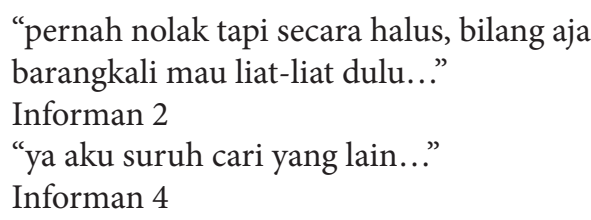

Semua informan mempunyai perilaku yang positif dalam merayu pelanggan namun tidak semua pelanggan mau memakai kondom dengan alasan akan mengurangi kenikmatan seksual. WPS menjadi kalah posisi dan melakukan hubungan seks tanpa menggunakan kondom. Nur Azmi (2008) yang menyebutkan bahwa ketidakberhasilan penggunaan kondom yang tidak konsisten disebabkan oleh posisi tawar menawar WPS yang lemah. Posisi tawar menawar yang lemah serta pemenuhan kebutuhan WPS terhadap kehidupan pribadi dan keluarga menjadi latar belakang WPS tidak konsisten menolak tamu yang tidak memakai kondom (Nur Azmi, 2009). Berdasarkan penelitian Mahalul Azam, dkk (2013), menyatakan bahwa $80 \%$ pelanggan tidak mau menggunakan kondom. Selain itu, konsistensi penggunaan kondom ditentukan oleh pengetahuan responden tentang IMS, Sikap WPS dalam penggunaan kondom, akses informasi tentang IMS dan HIV AIDS, persepsi pelanggan tentang kemmpuan untuk melakukan perilaku seks secara aman, dan dukungan germo (Irwan Budiono, 2012).

Seluruh informan yang terdiri dari 6 informan (100\%) menyatakan bahwa mereka jarang memakai kondom. Hal ini disebabkan oleh sulitnya mereka membujuk tamu untuk memakai kondom. Para tamu merasa mereka sudah membayar jasa WPS untuk memuaskan mereka sesuai dengan keinginan mereka. Berikut penjelasannya:

"Kadang-kadang pake kadang-kadang
nggak. Ada aturan harus pakai dari
kesehatan buat make kondom tapi kan ada
tamu yang gak bisa kita atasin. Ya kadang
juga bisa diatasi."
Informan 1
"Kadang pake kondom kadang nggak.
Ya misalkan saya merayu tamu, tapi kalo
tamu gak mau berarti kita gak dapet rejeki.
Padahal kesini ya buat cari uang. Tapi ya
yang penting sebelum masukin, kitanya
sama-sama bersihin dulu."
Informan 4

Adapun frekuensi tamu WPS yang memakai kondom hanya 1 orang dalam 1 minggu atau hanya 25\% tamu WPS yang mau menggunakan kondom dalam 1 minggu (dari 4 tamu hanya 1 yang memakai kondom). Selain tamu atau pelanggan yang menolak untuk memakai kondom, terdapat informan yang justru menyuruh pasangan seksualnya untuk tidak memakai kondom. Informan menganggap pasangannya tersebut seperti suami sendiri sehingga tidak perlu memakai kondom. Informan yang lain juga mengaku jika dengan pacar atau dengan orang yang mereka suka, mereka tidak akan memakai kondom, karena mereka menganggap sudah mengenal pacar dan tahu keseharian pacar mereka. Berikut penjelasannya :

\footnotetext{
"tapi ada ya, walaupun bukan suami, ntar aku malah nyuruh ga usah pake kondom.." Informan 1

"kalo sama pacar ya nggak, kan udah tau sehari-harinya gimana.."

Informan 3
}

Sebanyak 6 informan (100\%) mengaku bahwa mereka mengetahui cara memakai kondom untuk dipasangkan ke tamu atau pelanggan mereka. Berikut penjelasannya:

"Ya sengertine enyong ya, sing penting dilebokna bae neng gane wong lanang mbak.. kan ada lipetane mbak, ya tinggal dimasukin aja. Aja kuwalik lah pokoke...." 


\section{Informan 6}

"Ya insyaAllah tau, kalo kita setelah buka kemasannya, jangan dipegang bawahnya. Pegangnya lingkarannya. Kalo bawahnya kan ntar pelumasnya bisa hilang. Terus masange sampe ful jangan setengah-setengah...."

Informan 5

Jarangnya pelanggan WPS memakai kondom bukan karena WPS tidak mengetahui cara memasangkan kondom dengan benar. WPS justru mahir memasang kondom mulai dari membuka kemasan kondom dengan hatihati, mengulurkan lingkaran kondom hingga ujung penis, hingga mencopot atau melepaskan kondom. WPS memasang kondom selalu dalam keadaan penis tegang dan cenderung melepaskan kondom dengan segera setelah pelanggan ejakulasi. Pengetahuan mereka tentang menggunakan kondom yang benar didapatkan dari berbagai sumber, antara lain penyuluhan, teman sepergaulan mereka dan selebaran cara penggunaan kondom pada kemasan kondom. Penggunaan kondom yang benar dapat mengurangi risiko tinggi terkena IMS. Hal ini sejalan dengan pernyataan Nur Fitriana dkk (2012) bahwa cara penggunaan kondom yang tidak sesuai aturan pemakaian merupakan faktor risiko kejadian IMS.

\section{Vaginal Higiene}

Sebanyak 5 dari 6 informan (83\%) membersihkan alat kelamin dengan air bersih dan sabun pembersih kewanitaan sedangkan 1 informan (17\%) membersihkan kelamin dengan pasta gigi. Cara membersihkan alat kelamin yaitu dengan "mengkorek-korek" vagina bagian dalam baik dengan sabun maupun pasta gigi. Berikut kutipannya:

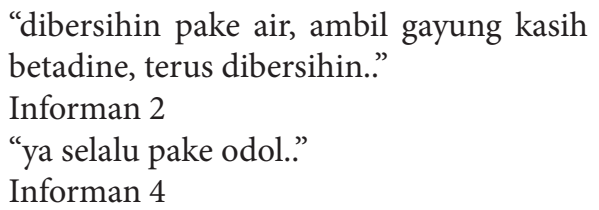

Informan menganggap kuman akan mati apabila alat kelamin dibersihkan dengan sabun pembersih kewanitaan (Edy W., 2009) ataupun dengan pasta gigi. Pendapat atau anggapan yang tidak benar namun berkembang di lokalisasi dapat mengakibatkan terhambatnya perubahan perilaku positif dalam mencegah
IMS. Sabun pembersih kewanitaan dan pasta gigi tidak seharunya digunakan untuk vagina bagian dalam karena dapat merusak vagina, serta merusak keseimbangan $\mathrm{pH}$ sehingga flora normal yang berada di kelamin wanita bisa mati dan membuat patogen penyebab IMS justru berkembangbiak.

Informan tidak begitu memperhatikan jenis kain celana dalam yang digunakan, 50\% tidak memilih jenis kain tertentu. Pemilihan jenis kain celana dalam yang mudah menyerap keringat dan tidak lembab bertujuan agar tidak terjadinya perkembangan bakteri patogen penyebab IMS.

Frekuensi mengganti celana dalam dan pembalut merupakan salah satu bagian dari vaginal higiene. Informan utama sudah memenuhi frekuensi minimal dalam mengganti celana dalam dan pembalut, yaitu minimal 2 kali dalam sehari untuk celana dalam dan minimal 3 kali dalam sehari untuk penggantian pembalut. Hal ini perlu dilakukan untuk menghindari alat kelamin dalam keadaan lembab dan tidak membuat bakteri patogen menyebab IMS berkembangbiak (Ditjen PPM\&PL, 2013).

Sebanyak 3 dari 6 informan (50\%) menyatakan bahwa mereka menyetrika celana dalam setelah dicuci. Sebanyak 100\% informan menyatakan bahwa mereka selalu mengeringkan alat kelamin setelah buang air kecil/buang air besar, serta $25 \%$ informan menggunakan celana dalam yang tidak ketat. Berikut penjelasannya:

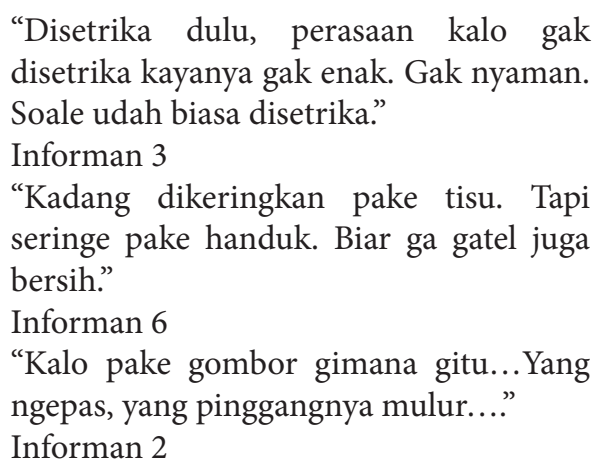
disetrika kayanya gak enak. Gak nyaman. Soale udah biasa disetrika." Informan 3

"Kadang dikeringkan pake tisu. Tapi seringe pake handuk. Biar ga gatel juga bersih."

Informan 6

"Kalo pake gombor gimana gitu...Yang ngepas, yang pinggangnya mulur....” Informan 2

Meskipun informan yang menyetrika celana dalam, mengeringkan alat kelamin dan menggunakan celana dalam yang tidak ketat belum mengetahui manfaat dari vaginal higiene yang telah mereka lakukan, tetapi secara tidak langsung mereka telah berperilaku 
positif dalam mencegah terjadinya IMS. Celana dalam yang telah dicuci bersih belum tentu bebas dari kuman. Meski telah dijemur di bawah sinar matahari. Untuk itu setelah celana dalam dicuci bersih, sudah seharusnya celana dalam disetrika terlebih dahulu sebelum dipakai kembali. Menyetrika celana dalam dapat membunuh bakteri patogen penyebab infeksi di daerah kelamin. Mengeringkan dengan tissu sekali pakai dan tidak beralkohol atau tidak berbau sangat dianjurkan, untuk menghindari kuman kembali dan mencegah terjadi iritasi pada bagian alat kelamin. Selain itu, pemakaian celana dalam yang longgar dapat memungkinkan sirkulasi udara yang lebih baik untuk kulit kelamin. Sehingga tidak terjadi kelembapan tinggi dan rasa gatal pada daerah kelamin.

Seluruh informan penelitian yang berjumlah 6 orang pernah mengalami IMS, hal ini didapatkan dengan menilik rekam medis hasil pemeriksaan bulanan (IMS mobile dari Puskesmas Jatibogor). Sebagian besar informan mengalami vaginosis bakterial dan servisitis, namun ada juga yang mengalami vegetasi/tumbuhan genital dan duh tubuh. Semua informan mendapatkan penanganan medis berupa pemberian obat-obatan yang diperlukan untuk menyembuhkan penyakit yang dialami informan dari petugas kesehatan Puskesmas Jatibogor ketika IMS mobile.

Kejadian IMS yang dialami informan penelitian dapat dipengaruhi oleh beberapa faktor antara lain penggunaan antiseptik atau sabun pembersih kewanitaan yang tidak semestinya (dilakukan terus-menerus dan dilakukan pada bagian dalam vagina) yang menyebabkan terganggunya $\mathrm{pH}$ di daerah kelamin sehingga patogen dapat hidup dan berkembangbiak dalam lingkungan alat kelamin, tidak konsistennya penggunaan kondom yang mengakibatkan semen residual setelah berhubungan seksual mengubah keseimbangan $\mathrm{PH}$ yang ada. Kejadian IMS yang tidak ditangani (tidak diobati) dan salah penanganan akan menimbulkan penyakit radang panggul, infertilitas, pelahiran kurang bulan spontan dalam kehamilan dan persalinan, keguguran pada trimester lanjut dan infeksi pascaoperatif setelah histerektomi (Gilly A., 2010).

\section{Penutup}

Berdasarkan hasil penelitian maka diperoleh informasi bahwa WPS cukup baik dalam mengakses informasi IMS melalui media cetak, petugas kesehatan maupun teman sesama WPS sehingga dapat meningkatkan pengetahuan tentang IMS. WPS belum cukup berhasil dalam bernegosiasi dengan pelanggan, sehingga perilaku pencegahan IMS melalui penggunaan kondom belum dapat terlaksana dengan baik. Penggunaan kondom yang benar sudah dilakukan WPS dengan baik, namun tidak konsistennya penggunaan kondom dalam setiap hubungan seksual dapat meningkatkan risiko IMS serta mengurangi keberhasilan upaya pencegahan IMS berupa penggunaan kondom dengan benar. Perilaku WPS di Lokalisasi Peleman dalam upaya pencegahan IMS melalui vaginal higiene belum baik karena masih terdapat kekeliruan informasi mengenai cara menjaga alat kelamin.WPS di Lokalisasi Peleman beresiko tinggi terkena IMS, baik ditimbulkan dari tidak memakai kondom saat melayani pelanggan maupun perilaku WPS dalam menjaga kebersihan kelamin.

\section{Daftar Pustaka}

Dewi Rokhmah. 2014. Implikasi Mobilitas Penduduk dan Gaya Hidup Seksual terhadap Penularan HIV AIDS, 9 (2).

Dinkes Propinsi Jateng. 2014. Data HIV dan AIDS Prov. Jateng per Juni 2013

Edy W. 2009. Praktik Wanita Pekerja Seks (WPS) Dalam Mencegah Penyakit Infeksi Menular Seksual (IMS) Dan HIV\&AIDS Di Lokalisasi Koplak, Kabupaten Grobogan, Jurnal Promosi Kesehatan Indonesia, 4 (2).

Elly Nurachmah dan Mustikasari. 2009. Faktor Pencegahan HIV/ AIDS Akibat Perilaku Berisiko Tertular Pada Siswa SLTP, Jurnal Makara Kesehatan, 13 (2): 63-68.

Gilly A. 2010. Buku Ajar Kesehatan Reproduksi Wanita, EGC, Jakarta

Hafrida, dkk. 2008. Evaluasi Promosi Penggunaan Kondom untuk Mencegah HIV/AIDS di Lokalisasi Pelacuran di Kabupaten Banyuwangi, Berita Kedokteran Masyarakat, 24 (3): 120-129

Irwan Budiono. 2012. Konsistensi Penggunaan Kondom Oleh Wanita Pekerja Seks/ Pelanggannya. Jurnal Kesehatan Masyarakat, 
$7(2)$

Mahalul Azam, Arulita Ika F, Muhammad Azinar. 2014. Model Integrasi Pendidik Komunitas dan Sistem Poin 'RP' (Reward-Punishment) untuk Pencapaian Condome Used 100\% di Lokalisasi, Jurnal Kesehatan Masyarakat, 10 (1).

Naila Kamila dan Arum S. 2010. Persepsi Orang dengan HIV AIDS Terhadap Peran Kelompok Dukungan Sebaya, Jurnal Kesehatan Masyarakat, 6 (1).
Nur Azmi, dkk. 2008. Analisis Faktor-Faktor Penyebab Niat Wanita Pekerja Seks (WPS) yang Menderita IMS Berperilaku Seks Aman (Safe Sex) dalam Melayani Pelanggan, Jurnal Promosi Kesehatan Indonesia, 3 (2): 103.

Nur Fitriana, dkk, 2012, Penggunaan Kondom dan Vaginal Hygiene sebagai Faktor Risiko Kejadian IMS pada WPS di Lokalisasi Batu 24 Kabupaten Bintan, Jurnal Kesehatan Masyarakat, Vol.I, Nomor 2, th.2012, hlm.357-363. 